\title{
Defense Mechanisms of Two Pioneer Submerged Plants during Their Optimal Performance Period in the Bioaccumulation of Lead: A Comparative Study
}

\author{
Dian Li, Linglei Zhang *, Min Chen, Xiaojia He, Jia Li and Ruidong An \\ Institute of Ecology and Environment, State Key Laboratory of Hydraulics and Mountain River Engineering, \\ College of Water Resource \& Hydropower, Sichuan University, Chengdu 610065, China; \\ lidian_1994@163.com (D.L.); chenm1004@gmail.com (M.C.); hexiaojia@scu.edu.cn (X.H.); lijia@scu.edu.cn (J.L.); \\ anruidong@scu.edu.cn (R.A.) \\ * Correspondence: zhanglinglei@scu.edu.cn; Tel.: +86-189-8210-0418
}

Received: 17 November 2018; Accepted: 12 December 2018; Published: 13 December 2018

\begin{abstract}
Ceratophyllum demersum L. and Hydrilla verticillata (L.f.) Royle, two pioneer, submerged plants, effectively remove heavy metals from contaminated water. The present work evaluates the bioaccumulation and defense mechanisms of these plants in the accumulation of lead from contaminated water during their optimal performance period. C. demersum and $\mathrm{H}$. verticillata were investigated after 14 days of exposure to various lead concentrations $(5-80 \mu \mathrm{M})$. The lead accumulation in both $C$. demersum and $H$. verticillata increased with an increasing lead concentration, reaching maximum values of 2462.7 and $1792 \mathrm{mg} \mathrm{kg}^{-1} \mathrm{dw}$, respectively, at $80 \mu \mathrm{M}$. The biomass and protein content decreased significantly in C. demersum when exposed to lead. The biomass of $H$. verticillata exposed to lead had no significant difference from that of the controls, and the protein content increased for the 5-10 $\mu \mathrm{M}$ exposure groups. The malondialdehyde (MDA) content and superoxide dismutase (SOD), peroxidase (POD), and polyphenol oxidase (PPO) activities were much higher in C. demersum, suggesting considerable damage from lipid peroxidation and sensitivity to lead stress. Enzyme inhibition and inactivation were also observed in C. demersum at high lead concentrations $(40-80 \mu \mathrm{M})$. The excellent growth status, low damage from lipid peroxidation, and high activity of catalase (CAT) and phenylalanine ammonia-lyase (PAL) observed in H. verticillata illustrate its better tolerance under the same lead stress.
\end{abstract}

Keywords: Ceratophyllum demersum L.; Hydrilla verticillate (L.f.) Royle; bioaccumulation; defense mechanism

\section{Introduction}

As one of the major heavy metals, lead $(\mathrm{Pb})$ has been an increasing concern for researchers because of its high toxicity, prevalent existence, persistence, and ubiquitous distribution [1]. $\mathrm{Pb}$ can have a negative impact on the morphology and growth status of plants [2], damage human health, and it does not have a beneficial effect on organisms [3]. Phytoremediation is an efficient, cost-effective, environmentally friendly method to address heavy-metal pollution with aesthetic value [4-6]. More than 500 species of plants have been documented to have an excellent ability to absorb extremely high levels of heavy metals $[7,8]$. Aquatic macrophytes act as important primary producers in aquatic ecosystems and possess considerable accumulation ability. Submerged plants possess a higher ability for the removal of heavy metals from wastewater than floating-leaved plants and emerged plants because they have a greater surface area and more biomass for the heavy metal accumulation $[6,9]$. The efficiency of phytoremediation greatly depends on the selection of an appropriate plant species for a particular heavy metal [10]. Thus, choosing a suitable submerged plant with high heavy metal 
accumulation ability is important for effective phytoremediation. According to Tangahu et al. [11], hyperaccumulators should survive despite the contaminant amounts they absorb. Two factors should be taken into consideration when selecting a plant for phytoremediation, i.e., its metal accumulation ability and metal tolerance characteristics.

Two submerged plant species were chosen for the experiments: Ceratophyllum demersum L. (Ceratophyllaceae family) and Hydrilla verticillata (L.f.) Royle (Hydrocharitaceae family). We selected these species for the following reasons: (1) They are cosmopolitan species distributed in temperate regions around the world, can adapt to many environmental conditions, and can be quickly cultivated in warmer regions [12-14], which means they can be used in phytoremediation more widely and economically. (2) Both species are among the most studied aquatic plants applied for phytoremediation and have been proven to possess excellent potential to accumulate various heavy metals from wastewater [15-19]. However, thus far, no experiments have been conducted to determine which of these two high-potential accumulator plant species possesses higher heavy metal accumulation ability under the same circumstances, and no comparison has been made to explore the similarities and differences in their defense mechanisms, especially during their optimal performance period.

Plants applied for phytoremediation should exhibit high and efficient absorption during their optimal performance period. According to previous studies, a period of 12-15 days has been proven to be an optimal performance period for plants treated with heavy metals [18,20-24]. Aquatic plants absorb considerable amounts of heavy metals but are not heavily poisoned after approximately 14 days of heavy metal exposure. For longer treatment times, the heavy metal accumulation in plants and the enzymes related to defense mechanisms may decrease, which have been proven in $C$. demersum and $H$. verticillata $[25,26]$. Therefore, 14 days is an optimal performance period for both species exposed to heavy metals and is also a representative period to reflect the bioaccumulation and tolerance characteristics of the plants.

As both species are pioneer plants with good accumulation ability, the defense mechanisms of these plants should be taken into consideration in the screening of plants for phytoremediation. This study explores the bioaccumulation and tolerance characteristics of $C$. demersum and H. verticillata during their optimal performance period and aims to determine which aquatic plant is a more efficient phytoremediator of $\mathrm{Pb}$ under various lead concentrations and how their defense mechanisms react to lead stress. In the present work, the comparisons of the defense mechanisms of these plants include the growth status, protein content, lipid peroxidation and antioxidant systems, etc. The performance of heavy metal accumulation ability and the defense mechanisms of plants during their optimal period could provide a criterion for the screening of hyperaccumulators.

\section{Materials and Methods}

\subsection{Plant Materials and Treatment Conditions}

C. demersum and H. verticillata without roots were collected from a plant market in Chengdu, China. After successively cleaning the plants with tap water and de-ionized water, the two plant species were placed in a $10 \%$ Hoagland nutrient solution [27] for a week to acclimatize them to the lab environment $\left(115 \mu \mathrm{mol} \mathrm{m} \mathrm{m}^{-2} \mathrm{~s}^{-1}\right.$ light with a 12 -h photoperiod at $\left.25 \pm 2{ }^{\circ} \mathrm{C}\right)$. C. demersum and H. verticillata ( 8 g per tank) were treated in 5 - $\mathrm{L}$ tanks filled with $3 \mathrm{~L}$ of different concentrations of $\mathrm{Pb}(5$, $10,20,40$ and $80 \mu \mathrm{M})$ in $10 \%$ Hoagland nutrient solution for 14 days. The initial concentrations of lead were determined on the basis of the characteristics of lead-contaminated water determined in previous studies. Plants treated without $\mathrm{Pb}$ served as the control groups.

\subsection{Quantification of Lead Bioaccumulation}

To comprehensively compare the accumulation abilities of the two plant species, the whole plants were compared instead of differentiating various tissues. C. demersum is difficult to separate into leaves and stems. The plant samples were thoroughly washed and dried at $75{ }^{\circ} \mathrm{C}$ and then digested 
in $\mathrm{HNO}_{3}: \mathrm{HCl}(4: 1, v / v)$. The lead content in the digested plants was determined using an atomic absorption spectrophotometer (Purkinje General Instrument Co., Ltd., Beijing, China) at $283.3 \mathrm{~nm}$ and is expressed as $\mathrm{mg} \mathrm{kg}^{-1} \mathrm{dw}$.

\subsection{Analysis of plant growth}

The plant biomass was determined by the fresh weight of the harvested plants. The protein content was estimated according to the method of Sedmak and Grossberg [28] and expressed as $\mathrm{mg} \mathrm{g}^{-1} \mathrm{fw}$.

\subsection{Lipid Peroxidation and Enzyme Activity Assays}

All of the biochemical assays were conducted at $4{ }^{\circ} \mathrm{C}$. Approximately $500 \mathrm{mg}$ of fresh plants was gathered, ground as a chilled tissue homogenate at $60 \mathrm{~Hz}$ for $75 \mathrm{~s}$ and then extracted with $5 \mathrm{~mL}$ of $20 \mathrm{mM}$ sodium phosphate buffer ( $\mathrm{pH} 7.0$ ) containing $0.5 \mathrm{mM}$ EDTA and $0.15 \mathrm{M} \mathrm{NaCl}$. The homogenate was centrifuged at $15,000 \times g$ for $5 \mathrm{~min}$ at $4{ }^{\circ} \mathrm{C}$, and the supernatant was used for the antioxidant enzyme activity analyses.

Lipid peroxidation was estimated from the malondialdehyde (MDA) content following the slightly adjusted method of Heath and Packer (1968). The superoxide dismutase (SOD) activity was measured via the inhibition of nitroblue tetrazolium (NBT) following the method of Beauchamp and Fridovich [29]. The catalase (CAT) activity was assessed by measuring the decomposition of hydrogen peroxide according to the method of Aebi [30]. The peroxidase (POD) activity was measured following the method of Zhang et al. [31]. The phenylalanine ammonia-lyase (PAL) and polyphenol oxidase (PPO) activities were measured based on the methods described by Hahlbrock and Ragg [32] and Gao et al. [33], respectively. All enzyme activity is expressed as units $\mathrm{g}^{-1} \mathrm{fw}$.

\subsection{Statistical Analysis}

SPSS 17.0 (IBM Inc., Chicago, IL, USA) was used to perform the statistical analyses, and all experiments were repeated three times. The homogeneity assumptions for variance and normal distribution were tested with Levene's test and Kolmogorov-Smirnov test, respectively. After the confirmation of these assumptions, one-way ANOVA was applied. For the F values, the degrees of freedom between and within groups were 1 and 4, respectively, and the total degrees of freedom was 5 . Duncan's multiple range test (DMRT) for post hoc multiple comparisons $(p<0.05)$ was also applied to assess the differences between treatments for each kind of plant and between different species of plants for each lead concentration.

\section{Results and Discussion}

\subsection{Lead Accumulation}

As shown in Table 1, the amount of lead accumulated by $C$. demersum and $H$. verticillata significantly depended on the lead concentration present in the nutrient solution $(\mathrm{F}=359.723, p<0.05$, $\eta^{2}=0.993 ; \mathrm{F}=869.689, p<0.05, \eta^{2}=0.997$ ). The level of lead accumulation in both plant species continued to increase with the increasing lead concentration, and the maximum lead accumulation in C. demersum and H. verticillata was $2482.7 \mathrm{mg} \mathrm{kg}^{-1} \mathrm{dw}$ and $1792.0 \mathrm{mg} \mathrm{kg}^{-1} \mathrm{dw}$, respectively, for the $80 \mu \mathrm{M}$ treatment. For each lead concentration, the lead accumulation amounts were different for the two plant species $(p<0.05)$. C. demersum had a better lead adsorption capacity. 
Table 1. Lead accumulation in Ceratophyllum demersum and Hydrilla verticillata exposed to different lead $(\mathrm{Pb})$ concentrations for 14 days.

\begin{tabular}{ccc}
\hline \multirow{2}{*}{ Concentration $(\boldsymbol{\mu M})$} & \multicolumn{2}{c}{ Pb Accumulation $\left(\mathbf{m g ~ k g}^{\mathbf{- 1}} \mathbf{d w}\right)$} \\
\cline { 2 - 3 } & C. demersum & H. verticillata \\
\hline 0 & $\mathrm{ND}$ & $\mathrm{ND}$ \\
5 & $626.0^{\mathrm{d}} \pm 36.7$ & $222.1^{\mathrm{e}} \pm 12.2$ \\
10 & $1510.0^{\mathrm{c}} \pm 135.0$ & $305.6^{\mathrm{d}} \pm 19.4$ \\
20 & $1653.8^{\mathrm{c}} \pm 77.7$ & $680.6^{\mathrm{c}} \pm 36.7$ \\
40 & $1992.9^{\mathrm{b}} \pm 110.3$ & $1000.4^{\mathrm{b}} \pm 23.5$ \\
80 & $2462.7^{\mathrm{a}} \pm 58.4$ & $1792.0^{\mathrm{a}} \pm 80.5$ \\
\hline
\end{tabular}

All values are the mean of triplicate measurements $\pm \mathrm{SD}(n=3)$. ANOVA was significant at $p<0.05$. Different letters indicate significantly different values for a particular plant species (Duncan's multiple range test (DMRT), $p<0.05)$.

Despite the controversial definition of 'hyperaccumulator' [34,35], both $C$. demersum and $H$. verticillata exhibited great potential to accumulate significant amounts of $\mathrm{Pb}$, which further verifies the findings of previous studies [15-19]. Obviously, C. demersum possesses a stronger ability to absorb lead. The difference in the lead accumulation ability of these two species may be related to the fractal dimensions (FDs), which indicate that the spatial occupation and utilization of the leaves of $C$. demersum are greater than those of $H$. verticillata [36]. The results are consistent with the findings of Li et al. [9] that a higher surface area enables higher uptake of heavy metals. The lead accumulation in both plant species exhibited an increasing tendency with increasing lead concentration. In the $10 \mu \mathrm{M}$ and $80 \mu \mathrm{M}$ exposure groups, the lead accumulation in C. demersum was 4.9 times and 1.4 times, respectively, that in H. verticillata. The lead accumulation in C. demersum exhibited a logarithmic increase with the increasing lead concentrations, with $\mathrm{R}^{2}=0.973$. The increasing lead accumulation in $H$. verticillata was well fitted by the quadratic polynomial model with $R^{2}=0.984$. This phenomenon suggests that as lead levels increase, the difference in the lead accumulation ability of these two species may further narrow. Speculations can be made that under higher concentrations of lead, the difference in FD may no longer play as important of a role in lead accumulation as that under lower concentrations, but the different defense mechanisms of plants instead become the governing factors. Thus, the defense mechanisms of plants should be further analyzed.

\subsection{Growth Status}

Biomass and protein content are good indicators of the growth performance of plants during lead exposure. The lead concentration had a significant influence on both the biomass and protein content of $C$. demersum $\left(\mathrm{F}=50.564, p<0.05, \eta^{2}=0.955 ; \mathrm{F}=83.507, p<0.05, \eta^{2}=0.972\right.$, respectively) and $H$. verticillata $\left(\mathrm{F}=3.365, p<0.05, \eta^{2}=0.584 ; \mathrm{F}=110.028, p<0.05, \eta^{2}=0.979\right.$, respectively).

Figure 1 shows that the biomass of both species showed slight increases at $5 \mu \mathrm{M}$ and then continually decreased with the increasing lead concentration. Because the plants were not greatly affected by lead toxicity after 14 days of exposure, the minimum biomass was observed with $80 \mu \mathrm{M} \mathrm{Pb}$ and was $72.0 \%$ and $93.1 \%$ of the levels in the controls for C. demersum and H. verticillata, respectively. The reduction in the biomass in plants treated with high lead concentrations verified the toxicity of $\mathrm{Pb}$. These macroscopic effects are mainly a result of toxic effects on cell constituents, water status, mineral nutrition, photosynthesis, and respiration [37]. The slight increase in biomass with low levels of $\mathrm{Pb}$ suggest that low doses of $\mathrm{Pb}$ may encourage plant growth, which was also observed in another study [38]. The biomass of $H$. verticillata treated with varying lead concentrations exhibited no significant differences compared to that of the controls $(p>0.05)$. The biomass in the $80 \mu \mathrm{M}$ exposure group was not significantly different from that of the controls even though the lead content in $H$. verticillata was $1792.0 \mathrm{mg} \mathrm{kg}^{-1} \mathrm{dw}$; the biomass was also higher than that of $C$. demersum exposed to $20 \mu \mathrm{M} \mathrm{Pb}$, with a lead accumulation of $1653.8 \mathrm{mg} \mathrm{kg}^{-1} \mathrm{dw}$. This phenomenon indicates the high growth status of $H$. verticillata despite the high lead content in the plants. 


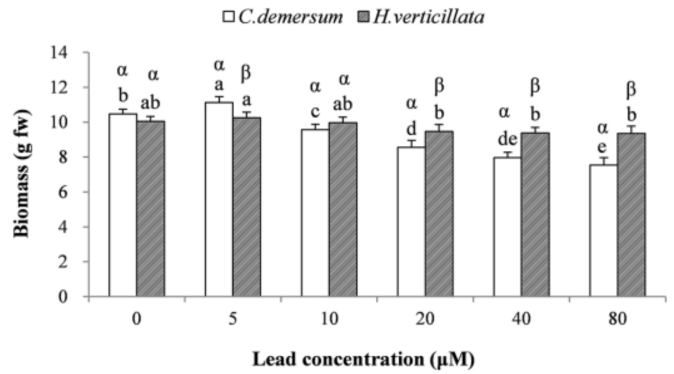

(a)

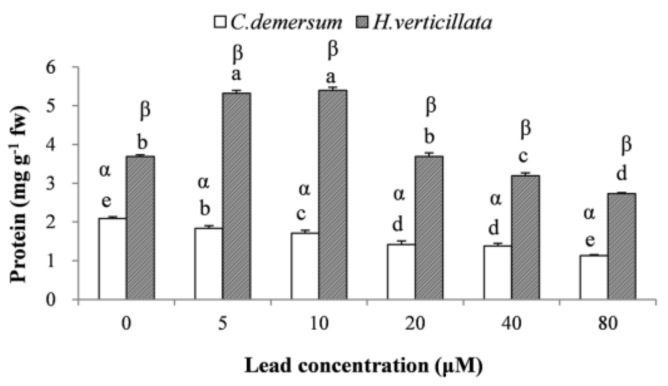

(b)

Figure 1. Effects of lead toxicity on (a) biomass and (b) protein content in Ceratophyllum demersum and Hydrilla verticillata. All values are the mean of triplicate measurements $\pm \operatorname{SD}(n=3)$. ANOVA was considered significant at $p<0.05$. Different Roman letters (a-f) and different Greek letters $(\alpha, \beta)$ indicate significant differences between concentrations for a plant species and significant differences between plant species for a concentration, respectively (Duncan's multiple range test (DMRT), $p<0.05$ ).

Compared with the biomass response, the protein content response was more sensitive to $\mathrm{Pb}$. $\mathrm{A}$ significant decrease in the protein content was observed in C. demersum, and the minimum value at $80 \mu \mathrm{M} \mathrm{Pb}$ was $54 \%$ of the value in the controls. It has already been noted that protein synthesis can be disturbed as a result of the harmful effects of heavy metals [39], and high concentrations of $\mathrm{Pb}$ may cause a reduction in the protein pool $[37,40]$. For $H$. verticillata, the protein content increased at low doses $(5$ and $10 \mu \mathrm{M})$ and then sharply decreased at high doses $(20 \sim 80 \mu \mathrm{M})$. The highest and lowest protein contents occurred at 10 and $80 \mu \mathrm{M} \mathrm{Pb}$ and were $146 \%$ and $74 \%$ of the levels in the controls, respectively. The results indicate that protein synthesis in $H$. verticillata was promoted in the presence of low levels of $\mathrm{Pb}$ and inhibited at high levels. This increase in the protein content may result from increased synthesis of defense proteins to resist lead toxicity, especially proteins that play a role in maintaining the redox status [37,41]. However, Mishra et al. [42] observed an induction in the protein content in $\mathrm{C}$. demersum exposed to $1-50 \mu \mathrm{M}$ lead for 2 days. The specific reason for the increase in the protein content of $C$. demersum was not observed in the present study, possibly because longer durations resulted in an increase in proteolytic activity induced by metal toxicity [43]. Therefore, the synthesis of defense proteins in $C$. demersum can be activated under a shorter exposure time (i.e., 2 days) and might be disturbed after a longer lead exposure time, such as 14 days. In contrast, the increased protein content observed in H. verticillata under the low lead concentrations at the 14th day seems to indicate its higher lead tolerance potential.

\subsection{Lipid Peroxidation Products and Antioxidant Enzymes}

Previous studies have reported that $\mathrm{Pb}$ induces oxidative stress by increasing the production of ROS (Reactive Oxygen Species) in plants [44], and then antioxidant systems are naturally activated to remove the toxicity of ROS [45]. MDA, which is a thiobarbituric acid reactive substance, is produced by lipid peroxidation and is widely used to indicate the extent of oxidative stress [24]. As MDA is not advantageous for plant growth, a high MDA content indicates that the stress tolerance of a plant is weak. The MDA content in both $C$. demersum and $H$. verticillata (Figure 2a) was significantly affected by the lead concentration $\left(C\right.$. demersum, $\mathrm{F}=230.744, p<0.05$, and $\eta^{2}=0.990 ;$ H. verticillata, $\mathrm{F}=291.855$, $p<0.05$, and $\left.\eta^{2}=0.992\right)$ and exhibited the same increasing trends corresponding to the increase in the lead concentration. Similar results were also reported by Dogan et al. [17] for C. demersum exposed to $\mathrm{Cd}$ and $\mathrm{Pb}$ and Song et al. [18] for $\mathrm{H}$. verticillata exposed to Ni. The MDA content in C. demersum and H. verticillata reached a maximum at $80 \mu \mathrm{M}$ and was $543 \%$ and $583 \%$, respectively, of the levels in the controls. Furthermore, the MDA content exhibited a strong positive correlation with lead accumulation in both $C$. demersum $\left(R^{2}=0.945\right)$ and $H$. verticillata $\left(R^{2}=0.979\right)$, which further indicates that lipid peroxidation in plants is directly associated with lead stress. For each lead concentration, the MDA 
content in $H$. verticillata was much lower than in C. demersum-approximately $20-40 \%$ of the levels in C. demersum-indicating that $H$. verticillata suffers lower damage from lipid peroxidation under the same lead concentration.

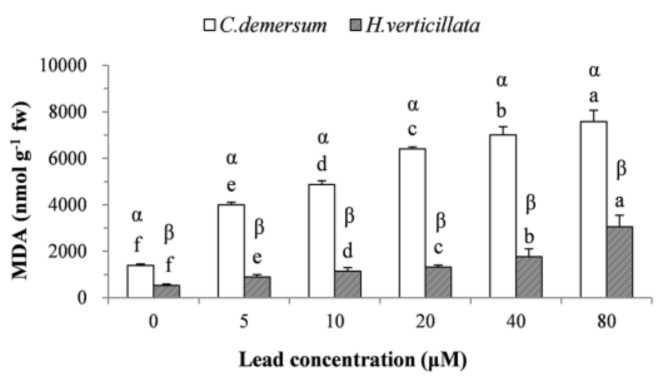

(a)

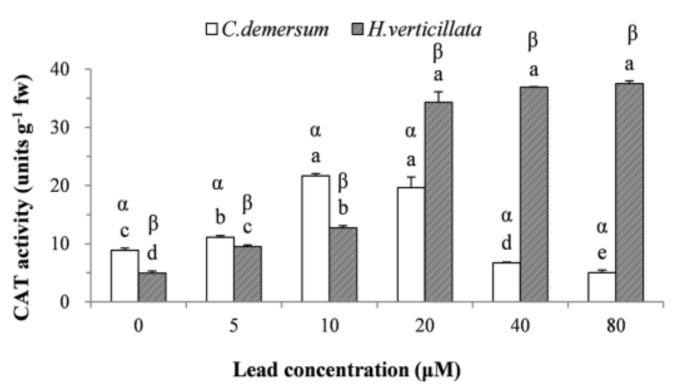

(c)

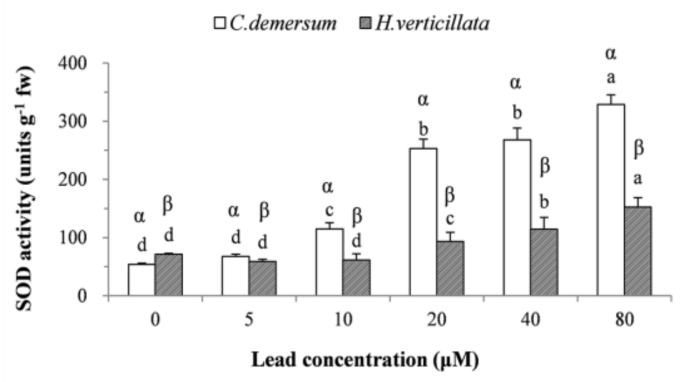

(b)

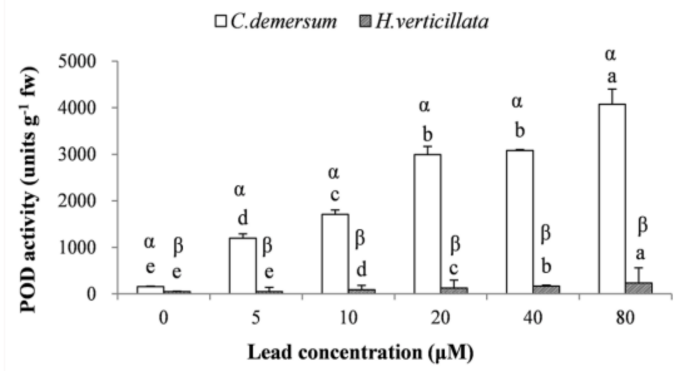

(d)

Figure 2. Effects of lead toxicity on (a) malondialdehyde (MDA), (b) superoxide dismutase (SOD), (c) catalase (CAT), and (d) peroxidase (POD) in C. demersum and H. verticillata. All values are the mean of triplicate measurements $\pm \mathrm{SD}(n=3)$. ANOVA was considered significant at $p<0.05$. Different Roman letters $(a-f)$ and different Greek letters $(\alpha, \beta)$ indicate significant differences between concentrations for a plant species and significant differences between plant species for a concentration, respectively (DMRT, $p<0.05)$.

SOD is the first line of defense in the antioxidant system and can alleviate the toxic effect of $\mathrm{O}^{2-}$ in plants [46]. $\mathrm{O}^{2-}$ is one of the major ROS produced in cells in the physiological state [10]. The significant changes in SOD activity (C. demersum: $\mathrm{F}=232.079, p<0.05$, and $\eta^{2}=0.990 ;$ H. verticillata: $\mathrm{F}=66.770$, $p<0.05$, and $\eta^{2}=0.965$ ) resulting from varying lead concentrations can be observed in Figure $2 \mathrm{~b}$. For both $C$. demersum and $H$. verticillata, the SOD activity increased with an increasing concentration of lead, and the maximum activity occurred at $80 \mu \mathrm{M}$, which was $609 \%$ and $214 \%$, respectively, of the levels in the controls. The results are consistent with the findings of Malar et al. [47] who observed a decline in the activity of SOD at a much higher lead concentration (approximately $4826 \mu \mathrm{M}$ ), which may be due to the inhibition of enzyme activity in the presence of excess $\mathrm{H}_{2} \mathrm{O}_{2}$. Compared to $H$. verticillata, the SOD activity in C. demersum was lower in the controls and higher in the $5 \sim 80 \mu \mathrm{M}$ exposure groups, suggesting that the SOD activity in $C$. demersum had a stronger response to lead stress than in H. verticillata. Moreover, the SOD activity in $H$. verticillata in the 5-10 $\mu \mathrm{M}$ exposure groups exhibited no significant difference from the controls, indicating its insensitivity to the low lead concentrations.

Both CAT and POD can decompose $\mathrm{H}_{2} \mathrm{O}_{2}$-another toxic ROS produced mainly by the activity of SOD-directly into $\mathrm{H}_{2} \mathrm{O}$ and $\mathrm{O}_{2}$ in plant cells and play important roles in the main defense mechanism [48]. As shown in Figure 2c, the CAT activity of both plant species was significantly influenced by the lead concentration $\left(C\right.$. demersum, $\mathrm{F}=222.411, p<0.05$, and $\eta^{2}=0.989 ;$ H. verticillata, 
$\mathrm{F}=162.170, p<0.05$, and $\left.\eta^{2}=0.985\right)$. For $C$. demersum, the CAT activity increased at low concentrations of lead and then declined. The decline was also observed in other studies [47,49], which might result from inactivation of the CAT enzymes due to excess production of ROS. Regarding H. verticillata, the CAT activity kept increasing with an increasing lead concentration. A positive correlation $\left(R^{2}=0.94\right)$ between the CAT activity and increasing lead concentration was observed in the $0-20 \mu \mathrm{M}$ exposure groups. The results suggest that CAT was continually activated as a defense mechanism to scavenge ROS, which agrees with the study by Asgari et al. [50]. However, the CAT activity did not exhibit significant changes at higher concentrations of lead $(20 \sim 80 \mu \mathrm{M})$, indicating that $H$. verticillata may have reached the limit of its ability to synthesize CAT enzymes. In contrast to our results, a decline in CAT activity with an increasing heavy metal concentration was observed in Lemna gibba L. [51] and Brazilian elodea [13]. Furthermore, the CAT activity in C. demersum was higher than that in $H$. verticillata at low concentrations $(0 \sim 10 \mu \mathrm{M} \mathrm{Pb})$ and lower at high concentrations $(20 \sim 80 \mu \mathrm{M} \mathrm{Pb})$. The results suggest that CAT activity in C. demersum was more easily induced under low lead stress, while $H$. verticillata exhibited better ability to activate CAT and defend against lead toxicity when the lead concentration was greater than $10 \mu \mathrm{M}$.

The POD activity (Figure 2d) in the two plant species increased significantly with the increasing $\mathrm{Pb}$ concentration $\left(C\right.$. demersum, $\mathrm{F}=245.461, p<0.05, \eta^{2}=0.990 ; H$. verticillata, $\mathrm{F}=398.458, p<0.05$, $\left.\eta^{2}=0.950\right)$ and reached a maximum at $80 \mu \mathrm{M}$. Positive correlations between the POD activity and lead concentration $\left(C\right.$. demersum, $\mathrm{R}^{2}=0.78 ; H$. verticillata, $\left.\mathrm{R}^{2}=0.95\right)$ were observed for both plant species. The significantly enhanced POD activity in the plants exhibited a close association with plant adaptation to severe lead stress. POD activity induced by heavy metal stress has also been reported by Li et al. [52] in Hibiscus cannabinus L. The maximum activity of POD was 26.0 and 4.8 times, respectively, that of the control value. Clearly, the POD activity in C. demersum was much higher than that in $H$. verticillata, indicating a more positive response to lead toxicity.

\subsection{PAL and PPO Enzyme Activities}

The significant effect $\left(C\right.$. demersum, $\mathrm{F}=114.482, p<0.05, \eta^{2}=0.979 ; \mathrm{H}$. verticillata, $\mathrm{F}=324.888$, $p<0.05, \eta^{2}=0.993$ ) of the lead concentration on PAL activity is presented in Figure 3a. The PAL activity in $C$. demersum increased gradually with the increasing lead concentration and reached a maximum at $40 \mu \mathrm{M}$. In $H$. verticillata, the PAL activity increased rapidly and reached a maximum at $80 \mu \mathrm{M} \mathrm{Pb}$. The changes in PPO activity are presented in Figure $3 \mathrm{~b}$. The PPO activity in C. demersum and $H$. verticillata had a significant response to the lead concentration (C. demersum, $\mathrm{F}=45.447, p<0.05$, $\eta^{2}=0.950 ;$ H. verticillata, $\left.\mathrm{F}=79.915, p<0.05, \eta^{2}=0.971\right)$. The POD activity of both plants increased gradually with the increasing $\mathrm{Pb}$ concentration.

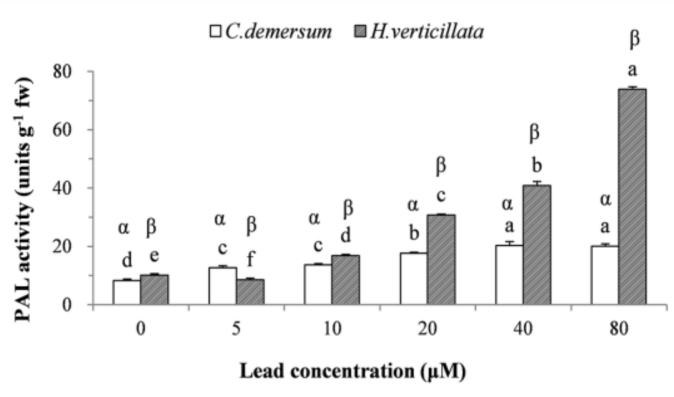

(a)

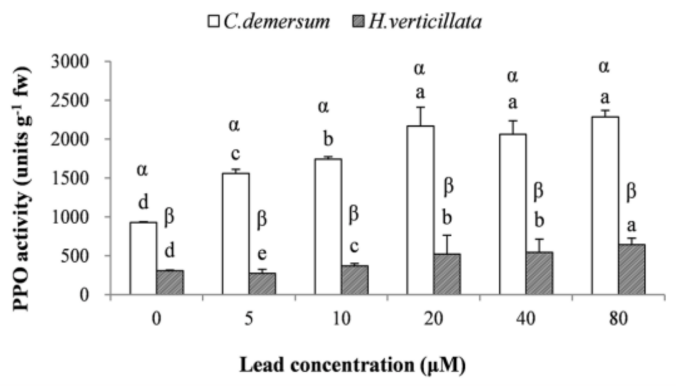

(b)

Figure 3. Effects of lead toxicity on (a) phenylalanine ammonia-lyase (PAL) and (b) polyphenol oxidase (PPO) in C. demersum and $H$. verticillata. All values are the mean of triplicate measurements $\pm S D$ $(n=3)$. ANOVA was considered significant at $p<0.05$. Different Roman letters $(\mathrm{a}-\mathrm{f})$ and different Greek letters $(\alpha, \beta)$ indicate significant differences between concentrations for a plant species and significant differences between plant species for a concentration, respectively (DMRT, $p<0.05$ ). 
We took PAL and PPO into consideration because they also perform defense-related functions. $\mathrm{PAL}$, an all-important enzyme in phenylpropanoid metabolic pathways, can be used to reflect the plant defense capacity and synthesis rate of metabolites [53]. PPO plays a key role in the photosynthetic apparatus and can provide a foundation for heavy metal accumulation in plants [54]. Based on enzymatic assays, PAL and PPO activities in plants have been shown to be significantly induced by exposure to lead and are correlated with the plant species and concentration of lead. Similar results for other heavy metals have also been reported by Kováčik and Bačkor [55] and Ahsan et al. [56]. However, Song et al. [18] reported a different result: an initial increase followed by a decrease in the activity of PPO was observed in $\mathrm{H}$. verticillata with increasing Ni concentration after 14 days of exposure, while the PAL maintained an increasing trend. Thus, the defense mechanisms in plants could lead to different responses to different heavy metals.

In this study, the PAL and PPO activities in both C. demersum and H. verticillata under lead stress exhibited significant differences compared to those in the controls, which indicates that a defense mechanism was activated in these plants. It should be noted that the PAL and PPO activities in both plant species exhibited the same increasing response with increasing lead concentration, whereas the activities of the two enzymes had the opposite trend. The PAL activity in $C$. demersum was weaker than in $H$. verticillata, while the PPO activity was stronger in C. demersum than in $H$. verticillata, which further indicates the different resistance mechanisms of the two plants. Moreover, for $C$. demersum, the PAL activities were not significantly different for the $40 \sim 80 \mu \mathrm{M}$ groups, and the same was true for the PPO activities of the $20 \sim 80 \mu \mathrm{M}$ groups, which suggests that the synthesis of the two enzymes were inhibited or hindered by high lead concentrations. However, significantly enhanced PAL and PPO activities were still observed in $H$. verticillata exposed to $80 \mu \mathrm{M} \mathrm{Pb}$.

There exist both similarities and differences in the defense mechanisms of the two plant species. In H. verticillata, the link among the SOD, CAT, and POD activities is obvious based on their parallel changes. The three enzymes were significantly stimulated by the increasing lead concentration, indicating their roles in removing oxygen free radicals and maintaining the normal metabolic balance of cells under lead stress. The antioxidative enzymes also had the same performance in C. demersum except that a decrease was observed in the CAT activity at high concentrations of lead, indicating that the production mechanism of CAT might be disrupted under high lead stress. C. demersum contains higher levels of SOD, POD, and PPO. Constable and Ryan [57] suggested that sensitive plants usually exhibit an induction of protective metabolites under stress. A higher sensitivity to lead stress was observed in C. demersum, as indicated by the higher induction of the activities of SOD, POD, and PPO, as well as the inhibition of CAT and PAL activities at high lead concentrations. This effect might be an explanation for the significantly decreased biomass and protein content in C. demersum. Furthermore, the CAT activity was much lower than that of SOD and POD in both species, which is consistent with the findings of Li et al. [24], indicating that the activities of SOD and POD were more easily activated for defense in the antioxidant enzyme system in the submerged plants. The growth status and defense mechanism of $H$. verticillata were excellent after 14 days of exposure, suggesting a high tolerance potential, which needs to be verified by further study.

Apart from the enzymatic activities analyzed in this study, plants also possess other mechanisms to resist heavy metal stress. For instance, phytochelatins, a class of metal chelators, can bind metal ions to reduce toxic effects, and its binding efficiency shows an increasing trend with increasing heavy metal concentration $[42,58]$. Nonprotein thiols have also been proven to affect the ROS/NO balance in plants, thereby affecting the metal accumulation ability [59]. Therefore, it will be very interesting to analyze the responses of various defense mechanisms in plants in further studies. Furthermore, there always exist other types of pollutants in the wastewater, such as ammonia, which may affect the lead accumulation in plants, and this should also be studied. 


\section{Conclusions}

In conclusion, both $C$. demersum and $H$. verticillate exhibited high potential to accumulate lead during their optimal performance period, and the lead accumulation ability of $C$. demersum was stronger. However, with an increase in the lead concentration, the increasing rate of lead accumulation in $C$. demersum gradually slowed and the growth status tended to be weaker. On the other hand, the lead accumulation in $H$. verticillate increased stably and the growth status was almost unaffected. That less damage was suffered by $H$. verticillate under the same lead concentration could also be demonstrated by the higher biomass and lower MDA content. Therefore, $H$. verticillate seemed to possess a stronger tolerance under the same lead stress, while $C$. demersum exhibited a much higher sensitivity. The excellent performance of the defense mechanism in $H$. verticillate might be related to the highly positive activity of CAT and PAL in the enzyme system. The other defense mechanisms in plants, such as phytochelatins, need to be further studied. The heavy metal accumulation ability and defense mechanisms of two pioneer, submerged plants during their optimal period provide criteria for the screening of hyperaccumulators.

Author Contributions: Conceptualization: L.Z. and J.L.; methodology: D.L. and M.C.; software: D.L. and X.H.; validation: X.H. and R.A.; writing—original draft preparation: D.L.; writing—review and editing: L.Z. and M.C.; supervision: J.L. and R.A.

Funding: This research was funded by the National Natural Science Foundation of China (Grants Nos. 51679156 and 91547211) and National Key R\&D Program of China (Grant No. 2016YFC0502207).

Conflicts of Interest: The authors declare no conflict of interest.

\section{References}

1. He, B.; Yun, Z.J.; Shi, J.B.; Jiang, G.B. Research progress of heavy metal pollution in China: Sources, analytical methods, status, and toxicity. Chin. Sci. Bull. 2013, 58, 134-140. [CrossRef]

2. Gill, M. Heavy metal stress in plants: A review. Int. J. Adv. Res. 2014, 2, 1043-1055.

3. Kumar, B.; Smita, K.; Flores, L.C. Plant mediated detoxification of mercury and lead. Arab. J. Chem. 2017, 10, S2335-S2342. [CrossRef]

4. Ali, H.; Khan, E.; Sajad, M.A. Phytoremediation of heavy metals-concepts and applications. Chemosphere 2013, 91, 869-881. [CrossRef] [PubMed]

5. Placek, A.; Grobelak, A.; Kacprzak, M. Improving the phytoremediation of heavy metals contaminated soil by use of sewage sludge. Int. J. Phytorem. 2013, 18, 605-618. [CrossRef] [PubMed]

6. Rezania, S.; Taib, S.M.; Din, M.F.M.; Dahalan, F.A.; Kamyab, H. Comprehensive review on phytotechnology: Heavy metals removal by diverse aquatic plants species from wastewater. J. Hazard. Mater. 2016, 318, 587-599. [CrossRef] [PubMed]

7. Rai, P.K. Heavy metal phytoremediation from aquatic ecosystems with special reference to macrophytes. Crit. Rev. Environ. Sci. Technol. 2009, 39, 697-753. [CrossRef]

8. Cappa, J.J.; Pilon-Smits, E.A.H. Evolutionary aspects of elemental hyperaccumulation. Planta 2014, 239, 267-275. [CrossRef]

9. Li, J.; Yu, H.; Luan, Y. Meta-analysis of the Copper, Zinc, and Cadmium absorption capacities of aquatic plants in heavy metal-polluted water. Int. J. Environ. Res. Public Health 2015, 12, 14958-14973. [CrossRef]

10. Yadav, K.K.; Gupta, N.; Kumar, A.; Reece, L.M.; Singh, N.; Rezania, S.; Khan, S.A. Mechanistic understanding and holistic approach of phytoremediation: A review on application and future prospects. Ecol. Eng. 2018, 120, 274-298. [CrossRef]

11. Tangahu, B.V.; Abdullah, S.R.; Basri, H.; Idris, M.; Anuar, N.; Mukhlisin, M. Phytoremediation of wastewater containing lead $(\mathrm{Pb})$ in pilot reed bed using Scirpus grossus. Int. J. Phytoremed. 2013, 15, 663-676. [CrossRef]

12. Sousa, W.T.Z.; Thomaz, S.M.; Murphy, K.J.; Silveira, M.J.; Mormul, R.P. Environmental predictors of the occurrence of exotic Hydrilla verticillata (L.f.) Royle and native Egeria najas Planch. in a sub-tropical river floodplain: The Upper River Paraná, Brazil. Hydrobiologia 2009, 632, 65-78. [CrossRef]

13. Maleva, M.; Borisova, G.; Chukina, N.; Kumar, A.; Prasad, M.N.V. High dose of urea enhances the nickel and copper toxicity in Brazilian elodea (Egeria densa Planch. Casp.). Braz. J. Bot. 2016, 39, 965-972. [CrossRef] 
14. Jain, M.S.; Kalamdhad, A.S. A review on management of Hydrilla verticillata and its utilization as potential nitrogen-rich biomass for compost or biogas production. Bioresour. Technol. Rep. 2018, 1, 69-78. [CrossRef]

15. Li, G.X.; Yan, C.Z.; Zhang, D.D.; Zhao, C.; Chen, G.Y. Cadmium(II) biosorption from aqueous solutions using Hydrilla verticillata. Can. J. Chem. Eng. 2013, 91, 1022-1030. [CrossRef]

16. Nigam, S.; Gopal, K.; Vankar, P.S. Biosorption of arsenic in drinking water by submerged plant: Hydrilla verticilata. Environ. Sci. Pollut. Res. 2013, 20, 4000-4008. [CrossRef]

17. Dogan, M.; Karatas, M.; Aasim, M. Cadmium and lead bioaccumulation potentials of an aquatic macrophyte Ceratophyllum demersum L.: A laboratory study. Ecotoxicol. Environ. Saf. 2017, 148, 431-440. [CrossRef] [PubMed]

18. Song, Y.; Zhang, L.L.; Li, J.; He, X.J.; Chen, M.; Deng, Y. High-potential accumulation and tolerance in the submerged hydrophyte Hydrilla verticillata (L.f.) Royle for nickel-contaminated water. Ecotoxicol. Environ. Saf. 2018, 161, 553-562. [CrossRef]

19. Maleva, M.; Borisova, G.; Chukina, N.; Kumar, A. Urea increased nickel and copper accumulation in the leaves of Egeria densa (planch.) Casp. and Ceratophyllum demersum L. during short-term exposure. Ecotoxicol. Environ. Saf. 2018, 148, 152. [CrossRef]

20. Jain, S.K.; Vasudevan, P.; Jha, N.K. Removal of some heavy metals from polluted waters by aquatic plants: Studies on duckweed and water velvet. Biol. Wastes 1989, 28, 115-126. [CrossRef]

21. Rai, U.N.; Sinha, S.; Tripathi, P.; Chandra, P. Wastewater treatability potential of some aquatic macrophytes: Removal of heavy metals. Ecol. Eng. 1995, 5, 5-12. [CrossRef]

22. Abdallah, M.A. Phytoremediation of heavy metals from aqueous solutions by two aquatic macrophytes, Ceratophyllum demersum and Lemna gibba L. Environ. Technol. 2012, 33, 1609-1614. [CrossRef] [PubMed]

23. Selamat, S.N.; Halmi, M.I.E.B.; Abdullah, S.R.S.; Idris, M.; Hasan, H.A.; Anuar, N. Optimization of lead (pb) bioaccumulation in Melastoma malabathricum L. by response surface methodology (RSM). Rendiconti Lincei Scienze Fisiche E Naturali 2018, 29, 43-51. [CrossRef]

24. Li, B.; Gu, B.W.; Yang, Z.G.; Zhang, T. The role of submerged macrophytes in phytoremediation of arsenic from contaminated water: A case study on Vallisneria natans (Lour.) Hara. Ecotoxicol. Environ. Saf. 2018, 165, 224-231. [CrossRef] [PubMed]

25. Chen, M.; Zhang, L.L.; Li, J.; He, X.J.; Cai, J.C. Bioaccumulation and tolerance characteristics of a submerged plant (Ceratophyllum demersum, L.) exposed to toxic metal lead. Ecotoxicol. Environ. Saf. 2015, 122, 313-321. [CrossRef] [PubMed]

26. Chen, M.; Zhang, L.L.; Tuo, Y.C.; He, X.J.; Li, J.; Song, Y. Treatability thresholds for cadmium-contaminated water in the wetland macrophyte Hydrilla verticillata (L.f.) Royle. Ecol. Eng. 2016, 96, 178-186. [CrossRef]

27. Hoagland, D.R.; Arnon, D.I. The water-culture method for growing plants without soil. Calif. Agric. Exp. Stn. Circ. 1950, 347, 1-32.

28. Sedmak, J.J.; Grossberg, S.E. A rapid, sensitive, and versatile assay for protein using Coomassie brilliant blue G250. Anal. Biochem. 1977, 79, 544-552. [CrossRef]

29. Beauchamp, C.; Fridovich, I. Superoxide dis-mutase: Improved assays and an assay applicable to acrylamide gels. Anal. Biochem. 1971, 44, 276-287. [CrossRef]

30. Aebi, H. Catalase. In Methods of Enzymatic Analysis; Bergmeyer, H.U., Ed.; Verlag Chemie Weinheim Academic Press: New York, NY, USA, 1974; p. 680.

31. Zhang, J.X.; Cui, S.P.; Li, J.M.; Kirkham, M.B. Protoplasmic factors, antoxidant responses, and chilling resistance in maize. Plant Physiol. Biochem. 1995, 33, 567-575.

32. Hahlbrock, K.; Ragg, H. Light-induced changes of enzyme activities in parsley cell suspension cultures: Effects of inhibitors of RNA and protein synthesis. Arch. Biochem. Biophys. 1975, 166, 41-46. [CrossRef]

33. Gao, S.; Chen, L.H.; Xu, Z.F.; Yuan, H. Changes of polyphenol oxidase activity during Jatropha curcas seed germination. J. Anim. Plant Sci. 2013, 18, 2659-2667.

34. Ent, A.V.D.; Baker, A.J.M.; Reeves, R.D.; Pollard, A.J.; Schat, H. Hyperaccumulators of metal and metalloid trace elements: Facts and fiction. Plant Soil 2013, 362, 319-334. [CrossRef]

35. Goolsby, E.W.; Mason, C.M. Response: Commentary: Toward a more physiologically and evolutionarily relevant definition of metal hyperaccumulation in plants. Front. Plant Sci. 2016, 6, 1252. [CrossRef] [PubMed]

36. Pan, W.B.; Li, D.F.; Tang, T.; Cai, Q.H. Studies on fractal character of macrophytes' leaves. Acta Hydrobiol. Sin. 2004, 28, 23-28. (In Chinese) 
37. Pourrut, B.; Shahid, M.; Douay, F.; Dumat, C.; Pinelli, E. Molecular Mechanisms Involved in Lead Uptake, Toxicity and Detoxification in Higher Plants. In Heavy Metal Stress in Plants; Gupta, D.K., Ed.; Springer: Berlin/Heidelberg, Germany, 2013; pp. 121-147.

38. Singh, A.; Kumar, C.S.; Agarwal, A. Effect of lead and cadmium on aquatic plant Hydrilla verticillata. J. Environ. Biol. 2013, 34, 1027-1031. [PubMed]

39. Emamverdian, A.; Ding, Y.; Mokhberdoran, F.; Xie, Y. Heavy metal stress and some mechanisms of plant defense response. Sci. World J. 2015, 2015, 1-18. [CrossRef] [PubMed]

40. Singh, R.; Tripathi, R.D.; Dwivedi, S.; Kumar, A.; Trivedi, P.K.; Chakrabarty, D. Lead bioaccumulation potential of an aquatic macrophyte Najas indica are related to antioxidant system. Bioresour. Technol. 2010, 101, 3025-3032. [CrossRef] [PubMed]

41. El-Khatib, A.A.; Hegazy, A.K.; Abo-El-Kassem, A.M. Bioaccumulation potential and physiological responses of aquatic macrophytes to Pb pollution. Int. J. Phytoremed. 2014, 16, 29-45. [CrossRef]

42. Mishra, S.; Srivastava, S.; Tripathi, R.D.; Kumar, R.; Seth, C.S.; Gupta, D.K. Lead detoxification by coontail (Ceratophyllum demersum L.) involves induction of phytochelatins and antioxidant system in response to its accumulation. Chemosphere 2006, 65, 1027-1039. [CrossRef]

43. Romero-Puertas, M.C.; Palma, J.M.; Gómez, M.; Río, L.A.D.; Sandalio, L.M. Cadmium causes the oxidative modification of proteins in pea plants. Plant Cell Environ. 2002, 25, 677-686. [CrossRef]

44. Shahid, M.; Dumat, C.; Silvestre, J.; Pinelli, E. Effect of fulvic acids on lead-induced oxidative stress to metal sensitive Vicia faba, L. plant. Biol. Fertil. Soils 2012, 48, 689-697. [CrossRef]

45. Ojuederie, O.B.; Babalola, O.O. Microbial and plant-assisted bioremediation of heavy metal polluted environments: A review. Int. J. Environ. Res. Public Health 2017, 14, 1504. [CrossRef] [PubMed]

46. Gupta, D.K.; Huang, H.G.; Corpas, F.J. Lead tolerance in plants: Strategies for phytoremediation. Environ. Sci. Pollut. Res. 2013, 20, 2150-2161. [CrossRef] [PubMed]

47. Malar, S.; Vikram, S.S.; Favas, P.J.; Perumal, V. Lead heavy metal toxicity induced changes on growth and antioxidative enzymes level in water hyacinths [Eichhornia crassipes (Mart.)]. Bot. Stud. 2014, 55, 1-11. [CrossRef] [PubMed]

48. Singh, P.; Prasad, S.M. Antioxidant enzyme responses to the oxidative stress due to chlorpyrifos, dimethoate and dieldrin stress in palak (Spinacia oleracea L.) and their toxicity alleviation by soil amendments in tropical cropland. Sci. Total Environ 2017, 35, 985-999. [CrossRef] [PubMed]

49. Willekens, H.; Chamnongpol, S.; Davey, M.; Schraudner, M.; Langebartels, C.; Van, M.M.; Inzé, D.; Van, C.W. Catalase is a sink for $\mathrm{H}_{2} \mathrm{O}_{2}$ and is indispensable for stress defense in $\mathrm{C}_{3}$ plants. Eur. Mol. Biol. Org. 1997, 16, 4806-4816. [CrossRef]

50. Asgari, L.B.; Ghorbanpour, M.; Nikabadi, S. Heavy metals in contaminated environment: Destiny of secondary metabolite biosynthesis, oxidative status and phytoextraction in medicinal plants. Ecotoxicol. Environ. Saf. 2017, 145, 377-390. [CrossRef]

51. Parlak, K.U.; Yilmaz, D.D. Ecophysiological tolerance of Lemna gibba L. exposed to cadmium. Ecotoxicol. Environ. Saf. 2013, 91, 79-85. [CrossRef]

52. Li, F.T.; Qi, J.M.; Zhang, G.Y.; Lin, L.H.; Fang, P.P.; Tao, A.F.; Xu, J.T. Effect of cadmium stress on the growth antioxidative enzymes and lipid peroxidation in two kenaf (Hibiscus cannabinus L.) plant seedlings. J. Integr. Agric. 2013, 12, 610-620. [CrossRef]

53. Macdonald, J.M.J.; D'Cunha, G.B.D.B. Erratum: A modern view of phenylalanine ammonia lyase. Biochem. Cell Biol. 2007, 85, 759-759. [CrossRef]

54. Lavid, N.; Tel-Or, E. The involvement of polyphenols and peroxidase activities in heavy-metal accumulation by epidermal glands of the waterlily (nymphaeaceae). Planta 2001, 212, 323-331. [CrossRef] [PubMed]

55. Kováčik, J.; Bačkor, M. Phenylalanine ammonialyase and phenolic compounds in chamomile tolerance to cadmium and copper excess. Water Air Soil Pollut. 2007, 185, 1-4. [CrossRef]

56. Ahsan, N.; Lee, D.G.; Alam, I.; Kim, P.J. Comparative proteomic study of arsenic-induced differentially expressed proteins in rice roots reveals glutathione plays a central role during as stress. Proteomics 2008, 8, 3561-3576. [CrossRef] [PubMed]

57. Constabel, C.P.; Ryan, C.A. A survey of wound- and methyl jasmonate-induced leaf polyphenol oxidase in crop plants. Phytochemistry 1998, 47, 507-511. [CrossRef] 
58. Figueira, E.; Freitas, R.; Guasch, H.; Almeida, S.F. Efficiency of cadmium chelation by phytochelatins in Nitzschia palea (Kutzing) W. Smith. Ecotoxicology 2014, 23, 285-292. [CrossRef]

59. Kovacik, J.; Dresler, S.; Peterkova, V.; Babula, P. Metal-induced oxidative stress in terrestrial macrolichens. Chemosphere 2018, 203, 402-409. [CrossRef] 